\title{
Entrepreneurship as a Factor of the Migrant Capacity of Producing Social and Cultural Equality: The Case of Sikh Indian Entrepreneurs in Rome
}

\author{
Francesca Faggioni \\ University of Rome TRE - Department of Business Studies
}

Mario Pesce

\section{Abstract}

Currently strong frictions, uncertainties and contrasts characterize society, defined by many as being very complex. The global economic crisis that began in 2006 and especially in Italy became a social and cultural crisis, which affected all societies and nations increasing the distance between the socalled West (Latouche, 2006) and the rest of the world. In this context, migrations have progressively distinguished themselves as a phenomena with global characteristics that have taken the form of real diasporas (Cohen, 2008; Clifford, 1994; Said, 1993;) and which definitively represent the need for a moment of study, analysis and economic and social interpretation that can give vital feedback, not only to scholars and professionals, but also and above all to policy makers.

Keywords: entrepreneurship as a factor of the migrant capacity of producing social and cultural equality

\section{Introduction}

The paper describes the first results of a research project that started a year ago; it was structured in several phases with the general objective being to understand mechanisms underlying the concept of integration linked to the entrepreneurial factors expressed by foreign communities in Italy. In this sense, entrepreneurship (as well as religion) has been considered as the "presupposition" and "vector" of the process of the migrant inclusion and their community.

The study, through the ethnographic methodology and the theory of Serge Latouche on globalization, which he calls "westernization" (Latouche, 1989, 2005, 2011, 2013), was designed with the purpose to investigate "migrant capacity" of creating business and producing social inclusion, both cultural and economic through mixed governance and by using mixed cultural models. 
In the model used, the categories of: neo-colonialism, migrant governance and resistance (Theodossopoulos, 2014) are the semantic areas that preliminarily, (between anthropology and economics,) intersect which lead to more precise social and economic analysis. In addition, the model adopts a key to understanding entrepreneurial dynamics in light of the macro areas of the "onion" from the anthropologist and economist Hofstede (Hofstede, 1991), as a subsequent form of analysis and refutation of the evidence that emerged, as well as validation of the model itself.

The conduct of the social and economic analysis is one of the crucial pivots of the project, because it constitutes the changing settings that impact the entrepreneurial choices of the communities which were investigated, in which the ability of the latter to generate social, cultural and economic inclusion is manifested and formed.

It is indeed worth stressing that in the anthropological approach, more than in the economic one, social and economic analysis does not constitute a clear portrayal of the context, however it is enriched with further meaning. In fact, the population investigated, through ethnographic methodology, seen as public ethnography (Tedlock, 1991), together with the reflection on "field policies" (Olivier de Sardan,

2009) becomes the researcher's operative tool, because it enables them whilst modifying both the setting and the research model, and furthermore allowing them to address epistemological change and the possibility of intervention linked to it.

For this reason, in the first phase the research focused on analyzing the migrant capacity represented by the Sikh community in the Rome area, in order to validate the model as well as the semantic categories used by the research.

The Sikh diaspora constitutes a "significant example of a dispersed population in a global context" (Poli, 2007: 91). Italy (second only to England for Sikh migration) is estimated to have about one hundred thousand residents, we have a community present in the territory with heterogeneous forms of visibility, diversely integrated, capable of activating processes of inclusion and attentive to the processes of active citizenship and personal entrepreneurship. For these reasons, and for their diffusion throughout Italy, it is believed that the migrant community coming from Punjab is a primary socio-economic and anthropological source of social change (Gallo, 2012; Lum 2012).

Therefore, from an operational point of view and in relation to the research question, the paper summarizes the statistics of the last 5 years on migrant entrepreneurship in general, and particularly Sikh, it then continues with an ethnographic approach through the administration of 50 semi-structured interviews of privileged witnesses in order to picture the population which was investigated, as well as to integrate the study model which was used. This approach made it possible to enrich the statistics on migrant entrepreneurship to a substantial amount of 
qualitative data, as well as to obtain the first results of the cultural and business model adopted by the Sikh community in Rome.

In light of the emerging model, the project concludes with more general observations on the dynamics of inclusion by the entrepreneurial vector, highlighting the weaknesses and best practices of foreign entrepreneurship in the Lazio region.

\section{References}

[1] Cohen, R., 1997, Global Diasporas. An Introduction, London, UCL Press. Clifford, J., 1994, Diaporas, in: "Cultural Anthropology", 9/2, pp. 302-338.

[2] Cohen R., Global Diasporas: An Introduction, Seattle, University of Washington Press 1997

[3] Olivier de Sardan J.-P., 2009, La politica del campo. Sulla produzione di dati in Antropologia" in F. Cappelletto (a cura di), Vivere l'etnografia, SEID, Firenze: 27- 63.

[4] Hofstede G.H., 1991 Cultures and Organizations: Software of the mind. London, Mc Graw-Hill.

[5] Latouche S., 1989, L'occidentalizzazione del mondo, Torino, Bollati Boringhieri.

[6] Latouchje S., 2005, Come sopravvivere allo sviluppo. Dalla decolonizzazione dell'immaginario economico alla costruzione di una società alternativa, Torino, Bollati Boringhieri.

[7] Latouche S. 2011, Il tempo della decrescita. Introduzione alla frugalità felice, Milano, Eleuthera.

[8] Latouche S., 2013, dove va il mondo. Un decennio sull'orlo della catastrofe,Torino, Bollati Boringhieri.

[9] Lum k., 2012, Indian diversities in Italy: Italian Case Study, Badia Fiesolana, CARIM- India Research Report.

[10] Gallo E., 2012, "Creating Gurdwaras, Narrating Histories. Perspectives on the Sikh Diaspora in Italy", in South Asia Multidisciplinary Journal, 6, pp. 116.

[11] Poli F., I Sikh. La comunità dei <<discepoli >> dal Punjàb al Mondo, Edizioni Studio Domenicano, Bologna 2007.

[12] Said, E., 1993, Culture and Imperialism, London, Chatto \& Windus.

[13] Tedlock B., From Participant Observation to the Observation of Participation: The Emergence of Narrative Ethnography, in: Journal of Anthropological Research Vol. 47, No. 1 (Spring, 1991), pp. 69-94

[14] Theodossopoulos D., On De-Pathologizing Resistance, Pages 415-430, in: "Journal History and Anthropology, Volume 25, 2014. 